\title{
The Relationship between Work Engagement and Organizational Trust: A Study of Elementary School Teachers in Turkey
}

\author{
Bahadır Gülbahar ${ }^{1}$ \\ ${ }^{1}$ Turkish Department at the Faculty of Educational Sciences Faculty of the Ahi Evran University, Terme Caddesi, Kırşehir, \\ 40100, Turkey \\ Correspondence: Bahadır Gülbahar, Turkish Department at the Faculty of Educational Sciences Faculty of the Ahi Evran \\ University, Terme Caddesi, Kırşehir, 40100, Turkey.
}

Received: December 7, 2016

Accepted: January 6, $2017 \quad$ Online Published: January 12, 2017

doi:10.11114/jets.v5i2.2052

URL: http://dx.doi.org/10.11114/jets.v5i2.2052

\begin{abstract}
The relationships based on trust which are established by a teacher with a school's internal stakeholders can provide greater engagement in work. Teachers who are engaged in their jobs can be decisive in turning their schools into successful and effective schools. It is important to research the relationship between work engagement and organizational trust in teachers since these are two significant variables affecting the performance and productivity of employees. The main purpose of this study is to determine the relationship between elementary school teachers' sense/understanding of work engagement and their understanding of organizational trust. The research is a correlational research study. Its environment consisted of 4016 elementary school teachers. 559 of the teachers were included in the sample. In the research the "Utrecht Work Engagement Scale" and "Multipurpose T Scale" were appropriately/ favourably used. In this research, confirmatory factor analysis and reliability analyses were repeated in order to validate the structure described in the scale. In the research, it is concluded that there is a positive, high level of significant relationship between participant teachers' perceptions of work engagement and their perceptions of organizational trust.
\end{abstract}

Keywords: work engagement, organizational trust, elementary school teachers, teachers' perceptions

\section{Introduction}

Work has an important place in human life since it is the basic tool through which needs are met and the field of activity to which a large part of the day is allocated. Work engagement is one of the factors that affect an employee's performance and productivity at work. According to Bakker et al. (2008), work engagement means a "positive, fulfilling, effectively motivating state of work-related subjective well-being". Work engagement is an important index for the quality of working life. In addition, it is an important factor in understanding behaviors such as labor transfer, reluctance to work and absenteeism (Aryee, 1994). Thus, it is possible to say that work engagement in employees is a very important factor in terms of the performance and productivity of the employee.

Engagement is "love, respect and being close to and loyal to someone" (TLI (Turkish Language Institute) Dictionary, 2016). Moreover, it is a commitment that an individual shows to another individual, an opinion, an institution or something she/he sees as greater than her/himself as well as an obligation that she/he has to fulfil (Col, 2004). Work engagement can be defined as the cognitive belief state of the psychological identification of the employee with her/his job (Kanungo, 1982). Employees' psychological identification with the job ensures that they become energetic, effective and willing and fulfil the requirements of their profession while performing activities related to their work (Maslach \& Leiter 1997; Schaufeli \& Bakker, 2001). Believing in the work and accepting the values and objectives of the work is important in terms of work engagement (Gunluk, 2010). Work engagement can be seen as an important factor in increasing the performance of the employee and, thereby, the organization's level of efficiency.

Work engagement does not have the same meaning as organizational engagement. Employees can feel engaged not only with their organizations but also in their jobs (Engelberg-Moston et al., 2009). Work engagement can be affected by the employees' positive attitudes towards their jobs and organizations. Having a low level of intent to leave their job, job satisfaction and organizational engagement are among these attitudes (Demerouti et al., 2001; Schaufeli \& Bakker, 2001, Schaufeli, Taris \& Van Rhenen, 2008). Work engagement is also related to positive organizational behaviours such as personal initiative and motivation to learn, taking on additional roles and planning (Sonnentag, 2003; Salanova, Agut \& 
Peiró, 2005). Employees' trust in their organizations can also be included in these factors.

It can be said that trust is the determinant of good relationships and harmony between people. Trust is "a feeling of believing and engaging without fear, hesitation or suspicion" (TLI (Turkish Language Institution) Dictionary, 2016). Trust means that one side in a relationship is confident that the other side will not exploit his or her weakness (Korczynski, 2003). In other words, it means expecting positive behaviours and attitudes from other individuals (Kramer, 1999; Costa, 2003). Trust is a human feeling nourished and improved by mutual discussion, commitment and action, and is a concept based on honesty and integrity in the most general sense (Ayaz Yilmaz, 2005; Demircan \& Ceylan, 2003). Stakeholders in an organization also need to trust each other. Organizational trust is important for both stakeholders and organizations because problems will be encountered in attaining goals in an organization that has trust issues (Yilmaz, 2004). Trust forms the basis of harmonious and productive relationships, effective cooperation, and communication within the organization (Baier, 1986). In such an organizational environment, the performance and the productivity of the employee will increase. Therefore, it can be said that organizational trust is a variable that determines the organization's level of effectiveness.

Relationships that a teacher builds on trust with the other internal stakeholders in the school can provide a feeling of engagement with work. Teachers who are engaged in their work can also be decisive for transforming their schools into successful and efficient schools. In the accessible literature, there are no studies researching the relationship between teachers' perceptions of work engagement and perceptions of organizational trust, even though there are studies examining teachers' perception of work engagement and perceptions of organizational trust separately, or the relationship between work engagement and organizational trust and other variables (Ozer vd., 2006; Yilmaz, 2006a; Yilmaz, 2006b; Polat, 2007; Samanci, 2007; Cokluk-Bokeoglu \& Yilmaz, 2008; Tak \& Ciftcioglu, 2008; Arslan, 2009; Cerit, 2009; Yuksel, 2009; Bakker \& Bal, 2010; Zayim, 2010; Bas \& Sentürk, 2011; Caglar, 2011; Gokduman, 2012; Ozturk \& Aydin, 2012; Yildiz, 2013; Ayele, 2014; Shukla, 2014; Egriboyun, 2014; Yilmaz, 2015; Sancak, 2016; Tumkaya \& Ustu, 2016). It is important to research the relationship between work engagement and organizational trust in teachers since they are two important variables that affect employees' performance and productivity. The main purpose of this study is thus to reveal the relationship between elementary school teachers' perceptions of work engagement and perceptions of organizational trust. In accordance with this purpose, the statement of the problem is: "Is there a statistically significant relationship between elementary school teachers' perceptions of work engagement and their perceptions of organizational trust?"

\section{Method}

\subsection{Research Design}

The research is a correlational research study aiming to determine the relationship between elementary school teachers' perceptions of work engagement and their perceptions of organizational trust. Correlational research is research in which the relationship between two or more variables is examined without interfering with these variables in any way, and in which the relationship is described in the general sense (Buyukozturk et al., 2010; Fraenkel \& Wallen, 2009).

\subsection{Sample}

The research environment consisted of 4016 elementary school teachers who work in Kocasinan, Melikgazi and Talas districts of Kayseri (a city in Turkey). 559 of 4016 teachers, all of whom had an equal and independent possibilityof being selected in the study, were included in the sample by using the simple random sampling method (Buyukozturk et al., 2010). The sample is based on a $95 \%$ confidence interval and 0.05 error.

\subsection{Data Collection Tool and Application}

In the research the "Utrecht Work Engagement Scale" and "Multipurpose T Scale" were used.

The Utrecht Work Engagement Scale was developed by Schaufeli and colleagues (2002) to assess employees' work engagement. It was carried out on two different samples consisting of 314 university students and 619 employees. It consists of 3 factors, "vigor, dedication and adoption/engagement", and 17 items. The scale was adapted to Turkish by Eryilmaz and Dogan (2012). Confirmatory Factor Analyses were carried out and compared as a one-factor and three-factor and it was concluded that the three-factor structure achieved a higher level of compliance. The item total correlations were between 0.48 and 0.71 . The Cronbach Alpha reliability coefficient was 0.94 for the whole scale; it varied between 0.84 and 0.87 for its sub-factors. As a result of two implementations with 31 employees with a one month break to determine the test-retest reliability of the scale, it was determined that the reliability coefficient was 0.85 and the test-retest reliability coefficient varied between 0.69 and 0.89 for its sub-factors. The scale was scored as follows: "Certainly Not Appropriate": 1; "Not appropriate": 2; "Slightly Appropriate": 3; "Appropriate": 4; and "Completely Appropriate": 5. There was a reverse coded item in the scale. High scores obtained from the scale show that engagement is high. 
In this research, confirmatory factor analysis (CFA) and reliability analysis were repeated to validate the structure described above. CFA was applied to demonstrate the validity of the structure with the aim of evaluating whether the 3 -factor 17-item structure of the scale was valid or not. In the first CFA, it was found that there was no item having a statistically insignificant $t$ value.

Fit Index Values for "Utrecht Work Engagement Scale" are shown in Table 1.

Table 1. Fit index values related to reliability study of Utrecht Work Engagement scale

\begin{tabular}{lllllll}
\hline \multirow{2}{*}{ Fit Index } & $\chi^{2 /(\mathrm{df})}$ & RMSEA & SRMR & TLI/NNFI & CFI & NFI \\
\cline { 2 - 7 } & $410.30 /(112)=3.66$ & 0.069 & 0.060 & 0.99 & 0.99 & 0.99 \\
\hline
\end{tabular}

When the RMSEA and SRMR values are checked in Table 1, it is seen that they are below the 0.08 critical value and this shows that they have an acceptable fit index (Kline, 2010). It is also seen that CFI, NFI and TLI/NNFI values have an excellent fit index (Sumer, 2000). When the fit index values are examined, it is again seen that measurement model is validated, which was established with the total Utrecht Work Engagement Scale and its sub-factors. The CFA model for the Utrecht Work Engagement Scale is presented in Figure 1.

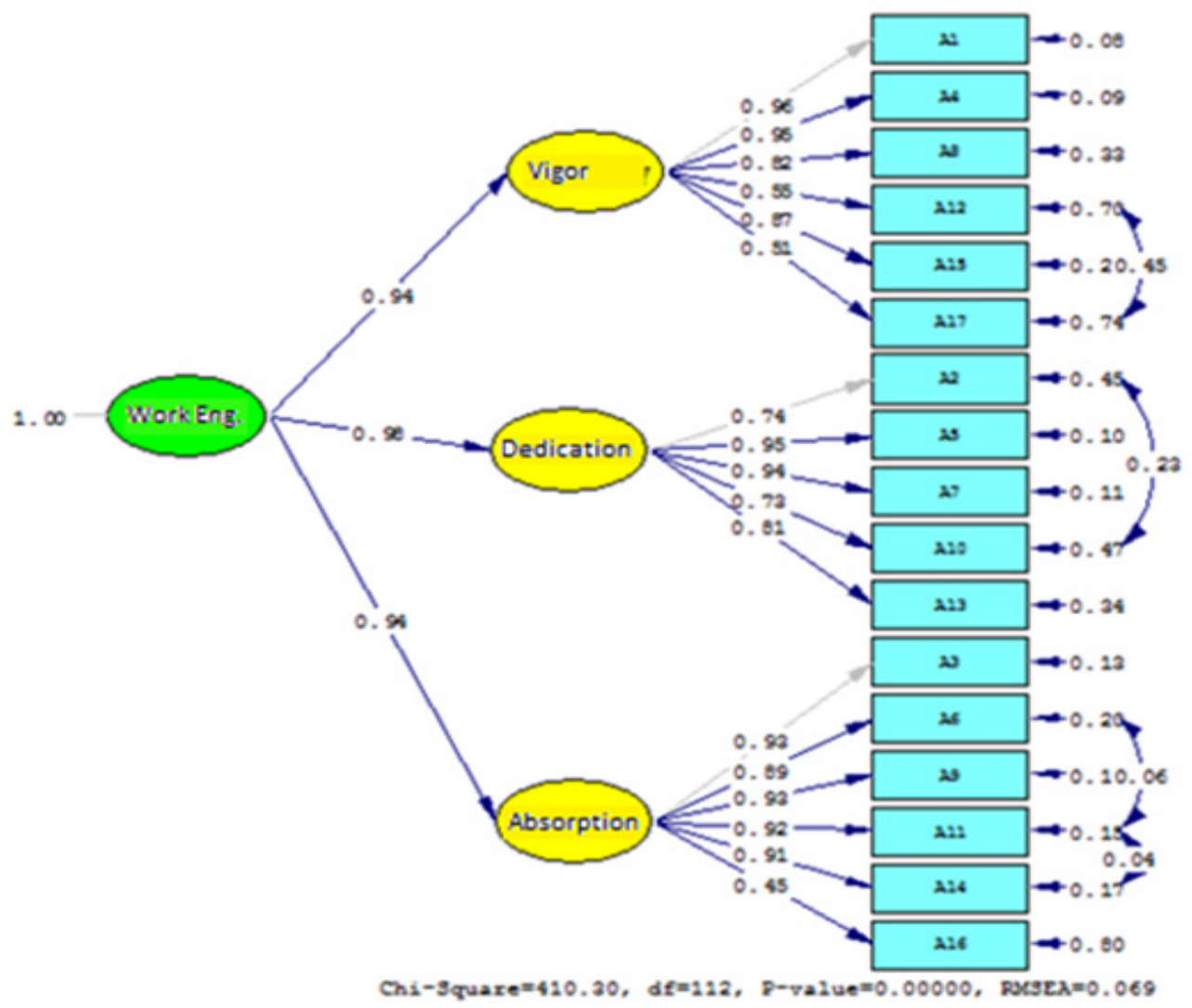

Figure 1. $2^{\text {nd }}$ level 3-factor CFA model for Utrecht Work Engagement scale

Reliability analysis results of the total Utrecht Work Engagement Scale and its sub-factors are shown in Table 2.

Table 2. Cronbach Alpha reliability results of total Utrecht Work Engagement scale and its sub-factors

\begin{tabular}{lcccc}
\hline & Vigor & Dedication & Absorption & Total Utrecht Work Engagement Scale \\
\hline Number of Items & 6 & 5 & 6 & 17 \\
\hline Cronbach $\alpha$ & .90 & .91 & .91 & .96 \\
\hline
\end{tabular}

Examining Table 2, it is understood that the total Utrecht Work Engagement Scale and its sub-factors have a high level of reliability and are sufficient because the Cronbach Alpha values are between 0.90 and 1.00 (Tezbasaran, 1997; Ozdamar, 1999).

The "Multipurpose T Scale" developed by Hoy and Tschannen-Moran (2003), which attempts to describe how teachers perceive the organizational trust level at schools, and which was adapted to Turkish by Ozer et al. (2006), was applied to 156 teachers working in a high school. It consists of 3 factors, "trust in colleagues", "trust in students and parents" and "trust in head teacher/principal" and 20 items. It was concluded that the reliability coefficients for the factors vary between 0.70 and 0.87 and the reliability coefficient for the total scale was calculated as 0.86 . 
In this research, confirmatory factor analysis and reliability analyses were repeated to validate the structure described above. CFA was applied to demonstrate the validity of the structure with the aim of evaluating whether the 3-factor 20 -item structure of the scale was valid or not. In the first CFA, it was found that there was no item having a statistically insignificant $t$ value.

Fit index values of the Multipurpose T Scale are presented in Table 3.

Table 3. Fit index values related to the reliability study of the Multipurpose T Scale

Fit Index

$\chi^{2 /(\mathrm{df})} \quad$ RMSEA $\quad$ SRMR $\quad$ TLI/NNFI $\quad$ CFI $\quad$ NFI

$\begin{array}{llllll}1683.75 /(661)=2.55 & 0.068 & 0.064 & 0.96 & 0.97 & 0.96\end{array}$

When the RMSEA and SRMR values are checked in Table 3, it is seen that they are below the 0.08 critical value and this shows that they have an acceptable fit index (Kline, 2010). It is also seen that CFI, NFI and TLI/NNFI values have an excellent fit index (Sumer, 2000). When the fit index values are examined, it is again seen that measurement model is valid, which was established with the total Multipurpose $\mathrm{T}$ Scale and its sub-factors. The CFA model for Multipurpose T Scale is presented in Figure 2.

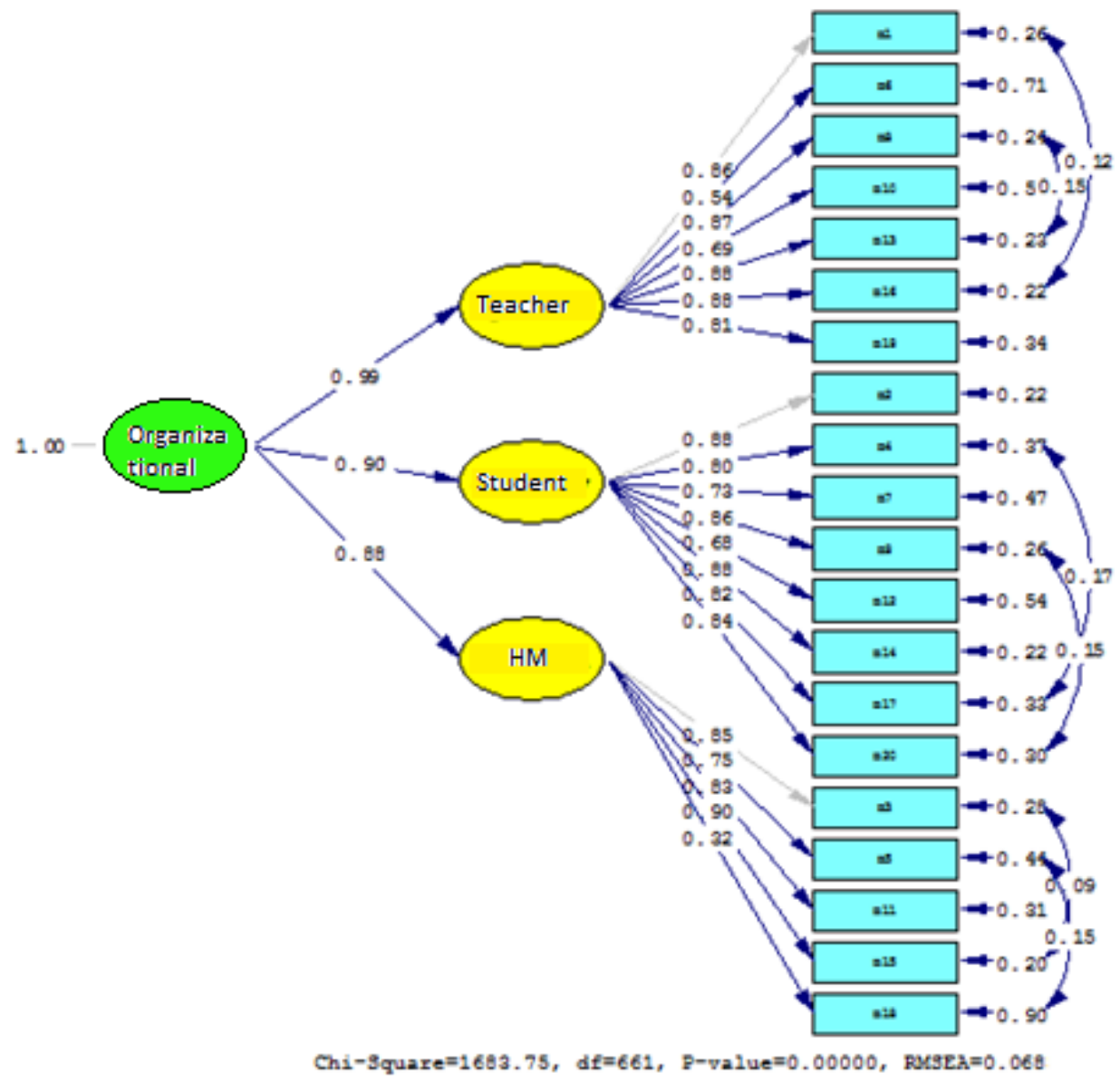

Figure 2. $2^{\text {nd }}$ level 3-factor CFA model for Multipurpose T Scale

Reliability analysis results of total Multipurpose T Scale and its sub-factors are seen in Table 4.

Table 4. Cronbach Alpha Reliability Results of Total Multipurpose T Scale and Its Sub-Factors

\begin{tabular}{lcccc}
\hline & $\begin{array}{c}\text { Trust in } \\
\text { Colleagues }\end{array}$ & Trust in Students and Parents & Trust in Headteacher & Total Multipurpose T Scale \\
\hline Number of Items & 7 & 8 & 5 & 20 \\
\hline Cronbach $\alpha$ & .97 & .91 & .97 & .97 \\
\hline
\end{tabular}

Examining Table 4, it is understood that total Multipurpose T Scale and its sub-factors have a high level of reliability and are sufficient because the Cronbach Alpha values are between 0.90 and 1.00 (Tezbasaran, 1997; Ozdamar, 1999). 


\subsection{Analysis}

The statistical package program SPSS (Statistical Package for Social Sciences, Version 21.0) was used for statistical analyses.

Second level 3-factor confirmatory factor analysis (CFA) was carried out to find out the validity of the two scales for the new participant group, which were previously validated and found reliable for the purpose of the research. The chi-square statistic, error indexes (RMSEA, SRMR), fit indexes (NFI, NNFI, CFI) were used to determine the validity of the measurement model.

Cronbach Alpha reliability analysis was used to evaluate the reliability coefficients of the total of the scales and their sub-factors.

The normality of the score distributions obtained from the scales and their sub-factors was evaluated by the the Kolmogorov-Smirnov $\mathrm{Z}$ test and the homogeneity by theLevene Homogeneity Test and it was found that the $\mathrm{p}$ value obtained for all values was above the critical value, 0.05 , and the score distribution was normal and test variations were homogeneous. It is understood that the measurement process was at an equally spaced scale level and continuous. As a result of the analyses, it is seen that parametric test assumptions were obtained.

The correlation between the scores obtained for the total of the scales and their sub-factors was examined by Pearson Correlation Analysis.

\section{Results}

\subsection{Elementary Teachers' Perception Levels of Organizational Trust and Work Engagement}

Table 5. Descriptive statistics related to elementary school teachers' perception levels of organizational trust and work engagement

\begin{tabular}{llllll}
\hline & $\mathrm{N}$ & Minimum & Maximum & Median & Standard Deviation \\
\hline Organizational Trust & 559 & 20.00 & 99.00 & $67.59(3.38)$ & 15.73 \\
Work Engagement & 559 & 17.00 & 85.00 & $63.88(3.76)$ & 12.84 \\
\hline
\end{tabular}

(Median Based on Item 67.59/20=3.38; 63.88/17=3.76)

Criteria: $1-1.80=$ very low; $1.81-2.61=$ low; $2.62-3.42=$ moderate; $3.43-4.23=$ high; $4.24-5.00=$ very high

When Table 5 is examined, it is seen that the elementary school teachers' perception levels regarding organizational trust was 67.59 (15.73). Considering the score of 3.38 obtained as a result of dividing the teachers' perceptions of organizational trust into a number of items, it is found that organizational level perceptions are at a "moderate" level (2.62-3.42).

It is seen that elementary school teachers' perception levels regarding work engagement is 63.88 (12.84). Considering the score of 3.76 obtained as a result of dividing the teachers' perception levels regarding work engagement into a number of items, it is found that teachers' perceptions regarding work engagement are at a "high" level (3.43-4.23).

3.2 The Relationship between Elementary School Teachers' Perceptions of Organizational Trust and Perceptions of Work Engagement

Table6. Pearson correlation analysis results of the relationship between elementary school teachers' perceptions of organizational trust and perceptions of work engagement

\begin{tabular}{lll}
\hline & & Total Work Engagement Scale \\
\hline \multirow{3}{*}{ Organizational Trust Perceptions } & $\mathrm{r}$ & $.71\left({ }^{* *}\right)$ \\
& $\mathrm{p}$ & .000 \\
& $\mathrm{r}^{2}$ (Explanation Variance) & 0.50 \\
\hline
\end{tabular}

$* * \mathrm{p}<.01$

When Table 6 is examined, it is seen that there is a positive, high level of significant relationship between elementary school teachers' perceptions of organizational trust and perceptions of work engagement. 
3.3 The Relationship between Elementary School Teachers' Perceptions of Trust in Their Colleagues and Perceptions of Work Engagement Related to the Total Work Engagement Scale and Its Sub-Factors "Vigor, Dedication and Absorption"

Table 7. Pearson correlation analysis results of the relationship between elementary school teachers' perceptions of trust in their colleagues and perceptions related to the total work engagement scale and its sub-factors

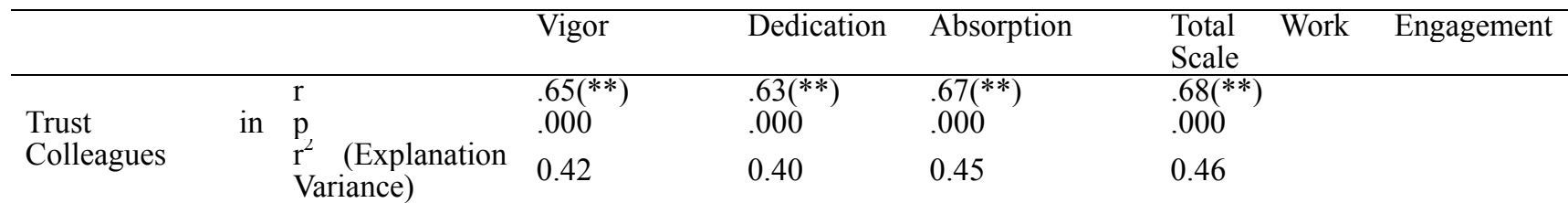

$* * \mathrm{p}<.01$

Examining Table 7, it is seen that there is a significant relationship which is positive at above a moderate level between teachers' perceptions of trust in their colleagues and perceptions of vigor according to $\mathrm{r}_{(559)}=.65, \mathrm{p}=.000$; there is a significant relationship which is positive at above the moderate level between teachers' perceptions of trust in their colleagues and perceptions of dedication according to $\mathrm{r}_{(559)}=.63, \mathrm{p}=.000$; there is a significant positive relationship which is close to a high level between teachers' perceptions of trust in their colleagues and perceptions of absorption according to $\mathrm{r}_{(559)}=.67, \mathrm{p}=.000$; there is a significant relationship which is positive at close to a high level between teachers' perceptions of trust in their colleagues and perceptions of work engagement according to $\mathrm{r}_{(559)}=.68, \mathrm{p}=.000$.

3.4 The Relationship between Elementary School Teachers' Perceptions of Trust in Students and Parents and Perceptions of Work Engagement Related to the Total Work Engagement Scale and Its Sub-factors "Vigor, Dedication and Absorption"

Table 8. Pearson correlation analysis results of the relationship between elementary school teachers' perceptions of trust in students and parents and perceptions related to total work engagement scale and its sub-factors

\begin{tabular}{|c|c|c|c|c|c|}
\hline & & Vigor & Dedication & Absorption & Total Work Engagement Scale \\
\hline \multirow{3}{*}{$\begin{array}{l}\text { Trust in Students } \\
\text { and Parents }\end{array}$} & $\mathrm{R}$ & $.56(* *)$ & $.58(* *)$ & $.61(* *)$ & $.61(* *)$ \\
\hline & $\mathrm{P}$ & .000 & .000 & .000 & .000 \\
\hline & $\begin{array}{l}\mathrm{r}^{2} \quad \text { (Explanation } \\
\text { Variance) }\end{array}$ & 0.31 & 0.34 & 0.37 & 0.37 \\
\hline
\end{tabular}

$* * \mathrm{p}<.01$

When Table 8 is examined, it is seen that there is a significant relationship which is positive at a moderate level between teachers' perceptions of trust in students and parents and perceptions of vigor according to $\mathrm{r}_{(559)}=.56, \mathrm{p}=.000$; there is a significant relationship which is positive at a moderate level between teachers' perceptions of trust in students and parents and perceptions of dedication according to $\mathrm{r}_{(559)}=.58, \mathrm{p}=.000$; there is a significant relationship which is positive at a little bit above a moderate level between teachers' perceptions of trust in students and parents and perceptions of absorption according to $\mathrm{r}_{(559)}=.61, \mathrm{p}=.000$; there is a significant relationship which is positive at a little bit above a moderate level between teachers' perceptions of trust in students and parents and perceptions of work engagement according to $\mathrm{r}_{(559)}=.61, \mathrm{p}=.000$.

3.5 The Relationship Between Elementary School Teachers' Perceptions of Trust in Head teacher and Perceptions of Work Engagement Related to The Total Work Engagement Scale and Its Sub-Factors Vigor, Dedication and Absorption"

Table 9. Pearson correlation analysis results of the relationship between elementary school teachers' perceptions of trust in head teacher and perceptions related to total work engagement scale and its sub-factors

\begin{tabular}{|c|c|c|c|c|c|}
\hline & & Vigor & Dedication & Absorption & Total Work Engagement Scale \\
\hline \multirow{3}{*}{ Trust in Headteacher } & $\mathrm{R}$ & $.68(* *)$ & $.57(* *)$ & $.67(* *)$ & $.67(* *)$ \\
\hline & $\mathrm{P}$ & .000 & .000 & .000 & .000 \\
\hline & $\begin{array}{l}\mathrm{r}^{2} \quad \text { (Explanation } \\
\text { Variance) }\end{array}$ & 0.46 & 0.32 & 0.45 & 0.45 \\
\hline
\end{tabular}

$* * \mathrm{p}<.01$

When Table 9 is examined, it is seen that there is a significant relationship which is positive at close to a high level between teachers' perceptions of trust in the head teacher and perceptions of vigor according to $\mathrm{r}_{(559)}=.68, \mathrm{p}=.000$; there is a significant relationship which is positive at a moderate level between teachers' perceptions of trust in the head teacher and perceptions of dedication according to $\mathrm{r}_{(559)}=.57, \mathrm{p}=.000$; there is a significant relationship which is positive at close to a high level between teachers' perceptions of trust in the head teacher and perceptions of absorption according to $\mathrm{r}_{(559)}=.67, \mathrm{p}=.000$; there is a significant relationship which is positive at close to a high level between teachers' perceptions of trust in the head teacher and perceptions of work engagement according to $\mathrm{r}_{(559)}=.67, \mathrm{p}=.000$. 


\section{Discussion, Result and Suggestions}

\subsection{Discussion}

The purpose of this research was to determine the relationship between elementary school teachers' perceptions of work engagement and perceptions of organizational trust. In the national and international literature, there are no studies examining the relationship between work engagement and organizational trust in teachers and this was the main reason for conducting this study. However, it was determined that there is research examining the relationship between work engagement and organizational trust in teachers and other concepts and variables in the accessible literature. Among this research, in a study in which Tschannen-Moran (1998) examined the relationship between trust and cooperation in primary schools, it was determined that trust is a factor that directly affects the level of cooperation between teachers, parents and students. In a study in which he examined the relationship between organizational change and organizational trust in schools, Lenz (2006) emphasizes that good communication between teachers and teachers' trust in the system of education will make work to reform educational institutions more successful. In research conducted by Caglar (2011), it was determined that there was a low level of negative relationship between organizational trust and level of burnout. In Yildiz's (2013) research, it was found that there was a positive, high level of relationship between teachers' perceptions of organizational justice and perceptions of organizational trust related to their schools. In research by Egriboyun (2014), it was found that there is a positive moderate level of relationship between teachers' perceptions of organizational trust and perceptions of organizational commitment. In the research conducted by Yilmaz (2015), it was determined that in a general sense there was a positive and weak relationship between teachers' perceptions of trust in the school and understanding of school conciousness.

In the research conducted by Tak and Ciftcioglu (2008), which is one of the research studies examining the relationship between work engagement and other variables in teachers, it was found that there is no direct causal relationship between teachers' professional commitment and intent to remain in the organization. In the research conducted by Shukla (2014), it was determined that there was a positive very high level of relationship between primary school teachers' work engagement and job satisfaction levels. In the research that Tumyaka and Ustu (2016) conducted on primary school teachers, it emerged that there was a negative high level of significant relationship between professional commitment and all dimensions of burnout.

The result that the participant teachers' perceptions of organizational trust are at a "moderate" level is consistent with the results of some studies in the literature. In the research conducted by Ozer et al. (2006), Samanci (2007), Cokluk-Bokeoglu and Yilmaz (2008), Cerit (2009) and Yilmaz (2015), it was found that teachers' organizational trust was at a moderate level. In the research carried out by Yilmaz (2006a), Yilmaz (2006b), Polat (2007), Yuksel (2009); Arslan (2009), Artuksi (2009), Bas and Senturk (2011) Ozturk and Aydin (2012), Yildiz (2013) and Aydug (2014), it was found that teachers' organizational trust was at a high level.

Teachers' organizational trust related to their schools should be at a greater than moderate level because a high level of organizational trust will raise the performance and the productivity of the teacher and that factor will bring success with it (Samanci, 2006). When there are teachers who a have high level of confidence in their schools and possess shared expectations and goals, this can impact positively on the quality of education and the effectiveness of the school (Hoy; Tarter; Witkoskie, 1992; Tarter; Sabo; Hoy, 1995; Goddard, Tschannen-Moran \& Hoy, 2001). Relations based on trust in an organization can create employees who trust in their headteachers and organizations, engage in their organizations emotionally, define themselves through their organizations, achieve job satisfaction and never consider leaving their organization (Demircan \& Ceylan, 2003). The high level of trust that teachers have in their organizations and that organizations have in their stakeholders will keep performance and productivity high and help teachers work in a committed way; this will raise the quality of education.

The result that participant teachers' perceptions of work engagement are at a "high" level is consistent with the results of other research in the literature. In the research they conducted, Tumyaka and Ustu found that teachers' work engagement was at a high level.

Society has handed the responsibility of preparing new generations for the future to teachers, through the teaching-learning process. Teachers who are engaged in their work should take different innovative teaching methods into consideration for effective learning and internalize these. However, only teachers who feel engaged in their work are able to consider and internalize these methods (Shukla, 2014). Work engagement is also a requirement for professional success (Goulet \& Singh, 2002). It is possible to state that the most innovative and open-minded teachers are those who have a high level of work engagement.

In this research, it has been determined that there is a positive, high level of significant relationship between elementary school teachers' perceptions of work engagement and perceptions of organizational trust. Thus, it is possible to say that a teacher with a high level of organizational trust will be more likely to be engaged in her/his work and that teachers 
should have a high level of organizational trust to have a high level of work engagement.

4.2 Result

This research concluded that there is a positive, high level of significant relationship between participant teachers' perceptions of work engagement and perceptions of organizational trust.

In the research, the findings below were obtained with relation to the participant teachers:

- Their perceptions of work engagement are at a high level and their perceptions of organizational trust are at a moderate level

- There is a significant relationship which is positive and close to a high level between their perceptions of trust in their colleagues and their perceptions of work engagement; there is a significant relationship which is positive and above a moderate level between their perceptions of vigor and perceptions of dedication; there is a significant relationship which is positive and close to a high level between their perceptions of absorption.

- There is a significant relationship which is positive and a little bit above a moderate level between their perceptions of trust in students and parents and perceptions of work engagement; there is a significant relationship which is positive and at a moderate level between their perceptions of vigor and perceptions of dedication; there is a significant relationship which is positive and a little bit above a moderate level between their perceptions of absorption.

- There is a significant relationship which is positive and close to a high level between their perceptions of trust in the headteacher and perceptions of work engagement; there is a significant relationship which is positive and close to a high level between their perceptions of vigor and perceptions of absorption; there is a significant relationship which is positive and at a moderate level between their perceptions of dedication.

\subsection{Suggestions}

- Studies could be conducted for determining the variables affecting the perceptions of work engagement and organizational trust in teachers. The reasons why the perception of organizational trust in teachers decreases could be researched.

- The same relational research could be conducted on primary school and high school teachers.

- Research could be conducted to examine the relationship between perceptions of work engagement and organizational trust in teachers in terms of demographic variables.

- The number of research studies related to the perception of work engagement in teachers could be increased.

\section{References}

Arslan, M. M. (2009). Perceptions of technical and industrial vocational high school teachers about organizational trust. Journal of theory and practice in education, 5(2), 274-288.

Artuksi, E. (2009). Primary school assistant teacher in the school of organizational trust level on the perception . Unpublished Master Thesis. İnönü University, Malatya.

Aryee, S. (1994). Jobinvolvement: an analysis of itsdeterminantsamongmaleandfemaleteachers. Revue Canadienne des Sciences de I'Administration, 11, 320-333. https://doi.org/10.1111/j.1936-4490.1994.tb00071.x

Ayaz, Y. A. (2005). Communication of trust in the relationship between doctor and patients. Unpublished Master Thesis. Akdeniz University, Antalya.

Ayduğ, D. (2014). Investigating relationships between primary schools' organizational health and teachers' organizational trust levels. Unpublished Master Thesis. Anadolu University Educational Sciences Institute, Eskişehir.

Ayele, D. (2014). Teachers' job satisfaction and commitment in general secondary schools of Hadiyazone, in southern nation nationalty and people of regional state. A Thesis Submittedto Department of Educational Planning and Management in Partial Fulfillment for the Requirements of Degree of Master of Arts in Educational Leadership, Jimma University, Ethiopia.

Baier, A. C. (1986). Trustandantitrust. Ethics, 96, 231-260. https://doi.org/10.1086/292745

Bakker, A., Schaufeli, W., Leiter, M., \& Tarıs, T. (2008). Work engagement: an emerging concept in occupational health psychology. Work \& Stress, 22(3), 187-200. https://doi.org/10.1080/02678370802393649

Bakker, B. A., \& Bal, P. M. (2010). Weekly work engagement and performance: a study among starting teachers. 
Journal of Occupational and Organizational Psychology, 83, 189-206. https://doi.org/10.1348/096317909X402596

Baş, G., \& Şentürk, C. (2011). Elementary school teachers' perceptions of organizational justice, organizational citizenship behaviours and organisational trust. Educational Administration: Theory and Practice, 17, 29-62.

Büyüköztürk, Ş., Çakmak, E. K., Akgün, Ö. E., Karadeniz Ş., \& Demirel, F. (2010). Scientific research methods. Pegem Publication, Ankara.

Cerit, Y. (2009). The relationship between organizational trust level and collaboration level of teachers. Uluda $\breve{g}$ University Journal of Education Faculty, XXII(2), 637-657.

Costa, A. C. (2003).Work team trust and effectiveness .Personnel Review, 32(5), 605-622. https://doi.org/10.1108/00483480310488360

Çağlar, Ç. (2011). An examination of teacher's occupational burnout levels in terms of organizational confidence and some other variables. Educational Sciences: Theory and Practice, 11(4), Güz/Autumn, 1827-1847.

Çokluk-Bökeoğlu, Ö., \& Yılmaz, K. (2008). Teachers' perceptions about the organizational trust in primary school. Educational Administration: Theory and Practice, 54, 211-233.

Çöl, G. (2004). Human resources, organizational commitment and relationship between similar concepts. Journal of $\dot{I}_{s}$, Güç, 6(2), 4-11.

Demerouti, E., Bakker, A. B., Janssen, P. P. M., \& Schaufeli, W. B. (2001). Burn out and engagement at work as a function of demands and control. Scandinavian Journal of Work, Environment \& Health, 27, 279-286. https://doi.org/10.5271/sjweh.615

Demircan, N., \& Ceylan, A. (2003). Concept of organizational trust: reasons and results. Gebze High Technology Institute Faculty of Management. Journal of Management and Economy, 10(2).

Eğriboyun, D. (2014). The relation between organizational trust and organizational support perceptions of the administrators and teachers who are charged in secondary education schools. Kafkas University Journal of the Institute of Social Sciences, 14(14), 329-363.

Engelberg-Moston, T., Stipis, C., Kippin, B., Spillman, S., \& Burbidge, K. (2009). Organisational and occupational commitment as predictors of volunteer coaches' burnout. Australian Journal on Volunteering, 14(1), 1-9.

Eryılmaz, A., \& Doğan, T. (2012). Subjective well-being at work: investigating of psychometric properties of utrecht work engagement scale. Journal of Clinical Psychiatry, 15, 49-55.

Fraenkel, J. R., \& Wallen, N. E. (2009). How to design and evaluate research in education (7th ed.). PA: McGraw-Hill.

Goddard, R. D., Tschannen-Moran, M., \& Hoy, W. K. (2001). A multi level examination of the distribution and effects of teachertrust in studentsandparents in urban elementaryschools. The Elementary School Journal, 102, 3-17. https://doi.org/10.1086/499690

Goulet, R. L., \& Singh, P. (2002). Careercommitment: reexamination and an extension. Journal of Vocational Behaviory, 61, 73-91. https://doi.org/10.1006/jvbe.2001.1844

Gökduman, D. (2012). Investigating the organizational trust perceptions of primary and secondary school teacher in terms of certain variables. Unpublished Master Thesis, Ahi Evran University Social Sciences Institute, Kırşehir.

Günlük, M. (2010). A research on accountants' professional and organizational commitment, job satisfaction and turnover intentions. Unpublished Master Thesis. Gebze High Technology Institute, Social Sciences Institute, Kocaeli.

Hoy, W. K., \& Tschannen-Moran, M. (2003). The conceptualization and measurement of faculty trust in schools. In Wayne K. Hoy \& Cecil Miskel (Ed.). Studies in leading and organizing schools, 181-207.

Hoy, W. K., Tarter, C. J., \& Witkoskie, L. (1992). Faculty trust in colleagues: linking the principal with school effectiveness. Journal of Research and Development in Education, 26, 38-45.

Kline, R. B. (2010). Principles and practice of structura lequation modeling. (3rd ed.) New York: Guilford.

Korczynski, M. (2003). Güvenin ekonomi politiği. (Çev: Ş. Erdem). In, F. Erdem (Ed.). Sosyal bilimlerde güven. Vadi Yayınları, Ankara.

Kramer, M. R. (1999). Trust and distrust in organizations: emerging perspectives, enduring questions. Annual Review of Psychology, 50, 569-598. https://doi.org/10.1146/annurev.psych.50.1.569 
Lenz, P. A. (2006). Teacher school board member trust relationships and their perceived influence on school effectiveness. Interdisciplinary Doctoral Program for Educational Leaders School of Education, Duquesne University.

Maslach C., \& Leiter M.P. (1997). The truth about burnout: how organizations cause personal stress and what to do about it. San Francisco, CA, Jossey-Bass, 125-176.

Özdamar, K. (1999). Statistical data analyses. Kaan Publications, Eskişehir.

Özer, N., Demirtaş, H., Üstüner, M., \& Cömert, M. (2006). High school teachers' perception of organizational trust. Journal of Ege Egitim, 7(1), 103-124.

Öztürk, Ç., \& Aydın, B. (2012). High school teachers' perception of organizational trust. Gaziantep University Journal of Social Sciences, 11(2), 485-504.

Polat, S. (2007). High school teachers' perception of organizational fair and relationship between their organizational trust level and organizational citizenship level. Unpublished Doctorate Thesis, Kocaeli University Social Sciences Institute, Kocaeli.

Salanova, M., Agut, S., \& Pieró, J. M. (2005). Linking organizational facilitators and work engagement to extra-role performance and customer loyalty: theme diating role of service climate. Journal of Applied Psychology, 2005, 90(6), 1217-1227.

Samanc1, G. (2007). Organizational trust and organizational citizenship behaviour. Sosyal Sciences Institute Unpublished Master Thesis, Afyon Kocatepe University, Afyonkarahisar.

Samanc1, S. (2006). Organizational atmosphere and organizational citizenship. Sosyal Sciences Institute Unpublished Master Thesis, Afyon Kocatepe University, Afyonkarahisar.

Sancak, Ö. (2016). A research to determine the relationship between organizational trust and organizational commitment. Unpublished Dissertation, Pamukkale University Sosyal Sciences Institute, Denizli.

Schaufeli W. B., Bakker A. B. (2001). Work and well-being: toward a positive approach in occupational health, 36-97.

Schaufeli, W. B., Taris, T. W., \& Van Rhenen, W. (2008). Workaholism, burnoutandengagement: Three of a kind or three different kinds of employee well-being. Applied Psychology: an International Review, 57(2), 173-203. https://doi.org/10.1111/j.1464-0597.2007.00285.x

Shukla, S. (2014).Teaching competency, professional commitment and job satisfaction-a study of primary school teachers. IOSR Journal of Research \& Method in Education, 4(3), 44-64.

Sonnentag, S. (2003). Recovery, work engagement, and proactive behavior: a new look at the interface between non-work and work. Journal of Applied Psychology, 88, 518-528. https://doi.org/10.1037/0021-9010.88.3.518

Sümer, N. (2000). Structural equality models: basis concepts and example practices. Journal of Turkish Psychology Writings, 3(6), 49-74.

Tak, B., \& Çiftçioğlu, B. A. (2008). An empiric research investigating the relationship between occupational commitment and the will of staying in the organization. Ankara University Journal of SBF. 63-4.

Tarter, C J., Sabo, D., \& Hoy, W. K. (1995). Middle school climate, faculty trust and effectiveness: a pathanalysis. Journal of Researchand Development in Education, 29 (1), 41-49.

TDK (2016). The uptodate Turkish dictionary of Turkish language association. RetrievedJune 24, 2016 from http://www.tdk.gov.tr

Tezbaşaran, A. (1997). The guide of developing likert type scale. Publiacation of The Association of Turkish Psychologists, Ankara.

Tschannen, M. M. (1998). Trust and collaboration in urban elementary schools. College of Education, Unpublished Doctorate Dissertation, The Ohio StateUniversity, U.S.A.

Tümkaya, S., \& Uş̧u, H. (2016). A research on primary school teachers: the relationship between exhaustion and occupational commitment. Journal of Mersin University Education Faculty, 12(1).

Yıldız, K. (2013). Teachers' organizational trust and organizational fair perceptions . Journal of AiB University Social Sciences Institute, 2013, 13(1), 289-316.

Yılmaz, E. (2006a). Investigation of the organizational trust level in schools in terms of certain variables. Journal of Selcuk University Social Sciences, 16, 739-756. 
Y1lmaz, E. (2006b). To investigate the effect of school managers' ethical leadership levels on the organizational trust level and to test whether the organizational trust level in schools differentiate with respect to some variables or not. Unpublished Doctorate Thesis. Selcuk University Social Sciences Institute, Konya.

Yilmaz, K. (2004). Primary school teachers' opinions about the relationship between trust in schools and the supportive leadership behaviours. Journal of Inonu University Edeucation Faculty, 5(8).

Yilmaz, K. (2015). Teachers' organizatonal awareness and organizational trust perceptions and level organizatonal effectiveness of schools. Unpublished Master Thesis, Adnan Menderes University Sosyal Sciences Institute, Aydin.

Yüksel, F. (2009). Relationship between organizational culture and organizational trust in primary sections. Unpublished Master Thesis. Istanbul Maltepe University Sosyal Sciences Institute, İstanbul.

Zayim, M. (2010). Investigating the relationship between primary and secondary level public school teachers' readiness for change and perceived organizational trust. Unpublished Master Thesis, Middle East Technical University Sosyal Sciences Institute, Ankara.

\section{Copyrights}

Copyright for this article is retained by the author(s), with first publication rights granted to the journal.

This is an open-access article distributed under the terms and conditions of the Creative Commons Attribution license which permits unrestricted use, distribution, and reproduction in any medium, provided the original work is properly cited. 